\title{
Democratic accountability and the terms of political order
}

\author{
Johan P. Olsen \\ ARENA, Centre for European Studies \\ University of Oslo
}

Accountability: A democratic concern

Making sense of the shifting significance of accountability

Political association: Unity, diversity and experience

Political organization: The ordering ideas, routines and resources of institutions

Political agency: Attention, acceptance and capabilities

Theorizing democratic accountability: Back to the roots

To appear in European Political Science Review 


\begin{abstract}
The aim of this paper is to make sense of the shifting significance of accountability processes and explain why they sometimes attract considerable public attention and citizens' involvement, whereas they at other times escape public notice. Accountability processes can be conceived of as order-maintaining or order-transforming processes - that is - they help police, sustain or strengthen political orders with well-defined rules and sanctioning unruly agents in addition to establishing order where none exists or challenging, reforming or replacing an existing order. I interpret recent obsession with democratic accountability as part of a struggle over the terms of political order in a period with contestations over the legitimate position of different territorial levels of government and the role of democratic politics in society. In such periods, more is at stake in accountability processes than an apolitical clarification of facts and causality and attempts to discipline incompetent or unruly agents.

Theorizing relationships between democratic accountability and political order brings political science back to its roots by calling attention to the kinds of activities democratic politics and governing are and the institutional contexts within which they typically take place. This kind of reflection is particularly important when established orders undergo are transformation, as is the case in Europe today. I therefore present a dynamic conception of accountability is presented that explores the importance of: (a) political association involving different mixes of unity/diversity, trust/mistrust and historical experiences. (b) Political organization and the ordering ideas, routines and resources of different institutions. (c) Political agency and shifting attention, zones of acceptance and action capabilities.
\end{abstract}

Key words: democratic accountability, political order, institutions, citizens, learning. 


\section{Accountability: A democratic concern}

Accountability arrangements, as relations between rulers and ruled, are assumed to be crucial for the democratic quality of a polity. A democratic vision is that citizens decide how they shall be organized and governed politically. In situations where a few make binding decisions on behalf of a community, democratic norms prescribe that they shall be accountable to the citizens. The greater the power of the decision makers, the more important it is to establish effective accountability mechanisms (March and Olsen 1995:152). Why then has public accountability become a buzzword and an obsession (Borowiak 2011, Dubnick 2011, Pollitt and Hupe 2011, Bovens, Goodin and Schillemans 2014)? Why do accountability processes sometimes attract considerable public attention and citizens' involvement, whereas at other times they escape public notice? When and why can we expect increased calls for accountability and what are drivers of demands for explanations, justifications and sanctions? ${ }^{1}$

I explore accountability relations in contemporary Europe. I give priority to accountability related to the terms of political order, the role of rank-and-file citizens, and the conditions under which accountability processes attract few or many participants and issues. Currently, the European state-centered order is challenged by Europeanization, internationalization and devolution, as well as competing ideas about the legitimate role of democratic politics in society. There are claims about the withering of the nation state, democratic deficit, the hollowing out of representative institutions, and legitimacy crisis. The aim of this paper is to provide an analytical framework for understanding the shifting significance of accountability processes. Increasing demands for accountability are interpreted as part of larger debates and struggles over the terms of political order.

Theorizing the relationship between political order and democratic accountability brings political science back to its roots. It calls attention to competing ways of thinking about political life and popular self-government: the kinds of activities democratic politics and governing are and the institutional contexts within which these activities typically take place in a specific area and era; the organization of authority, power, responsibility and

\footnotetext{
${ }^{1}$ An earlier version of the paper has been presented at seminars at the Comenius University, Bratislava and Utrecht University. Thanks for constructive comments to Jozef Batora and the participants in Bratislava, to Mark Bovens, Thomas Schillemans and the participants in Utrecht, and to three anonymous reviewers. A special thanks to James $\mathrm{G}$. March, friend and colleague over nearly 50 years.
} 
accountability; ways of handling conflicts and the conditions for legitimate order and change. This kind of reflection is particularly important when established orders are undergoing transformations, the situation in which Europe finds itself today. Accountability is, however, costly in terms of time, energy and resources and excessive monitoring damage trustrelations. As a result, there is search for and contestation over mutually acceptable balances between authorizing and restraining agents. In the following I present an analytical framework for understanding such balancing acts and I explore how the shifting significance of accountability processes is affected by three aspects of political order: political association, organization and agency.

\section{Making sense of the shifting significance of accountability}

An accountability relation involves actors obliged to render an account to other actors in a domain under specific circumstances, with the latter having the right and resources to require, assess and sanction the account. Accountability processes involve moral-ethical standards, facts and causality, as well as power and action capabilities. They can be interpreted as part of order-maintaining or order-transforming processes (Eisenstadt 1995), that establish order where none exists or challenge, reform or replace an existing order. They can be conceived of as apolitical, technical or political processes.

When accountability processes are seen as apolitical, technical policing, designed to sustain or strengthen an order, their task is to understand what happens and why - to detect errors, malpractice or criminal acts and to control and sanction incompetent and unruly agents. Accountability is a question of correct reporting, truth-finding and securing compliance with the established regime. Accountability assumes (near) consensus about political order and normative standards and implies enacting a polity's repertoire of routines and fulfilling role expectations, duties and commitments. Accounting and auditing specialists interpret and respond to experience using the standard operating procedures and templates of institutions and professions. They attribute responsibility, call the responsible parties to account, and recommend sanctions. The challenge is to secure effective accountability and improve government by incorporating experience into new routines.

Increasing demands for accountability are likely to reflect discontent with the causal, normative and power basis of the order or its development. Politics exists because 
individuals do not agree, and there is a perceived need to find compromises a community can live with (Mouffe 2005, Hay and Stoker 2009). As a consequence, more aspects of accountability have to be treated as endogenous to democratic politics, and accountability as a neutral technique has to be supplemented by accountability as politics, including public reasoning and contestation over what is a possible, reasonable and just political order.

Accountability conceived as politics within an existing political order also assumes that most people accept the order as legitimate. There may be causal uncertainty or disagreement about what is true and justifiable. Accountability processes, nevertheless, take place within institutional frames and orderly transfer of powers. For example, mainstream principalagent approaches assume pre-determined dyadic relations of principals and agents, competing policy preferences, and non-cooperative strategic games. Principals have the power to decide success criteria and incentives and there is asymmetric information in favor of agents (Gailmard 2014). The challenge is related to control and compliance, making agents comply with the principal's rules and goals, and preventing them from misusing their powers.

A democratic hope is that discontent with specific governments, politicians and political parties can be combined with trust in, and support of, the political order. Citizens may oppose the incumbents in office and still respect the office, and there may be reservoirs of favorable attitudes that make them tolerate policies they are against (Easton 1975). Arguably, criticism of policies and personnel, the ability to impose sanctions on decisionmakers who do not act in accordance with their mandates and the ability to replace governments provide a safety valve for loss of trust in, and revolt against the political order (Olsen 2010).

Accountability theory, nevertheless, cannot assume agreement on political order. A political order is an institutional arrangement for allocating authority, power, information, responsibility and accountability. At times, and in some areas, political life is highly institutionalized. There are well defined boundaries, institutionalized rules and practices, shared normative and causal understandings and adequate collective resources. At other times and other places political life is less orderly. Boundaries are less well-defined. There are fewer and weaker institutions and enduring divisions and antagonisms, i.e. competing 
allegiances and loyalties, normative and causal understandings, and less adequate common resources. Over time, political life achieves or loses structure, and the nature of order changes (March and Olsen 1998:303-304).

The paper, therefore, addresses accountability related to the politics of the terms of political order - situations where established institutional arrangements have limited legitimacy and public support. There is no dominant interpretation of legitimate order and determining who-is-accountable-to-whom-for-what is part of the processes through which order is formed, maintained and changed (Olsen 2015). The politics of accountability involves struggle over political association: the borders of political entities and who shall belong to "the people", collective identity, dividing lines and how to live together; political organization: what are legitimate roles, rules and resources of good governmental institutions; and political agency: what are legitimate individual actions, motivations and resources in different institutional contexts. In such processes authority, power and trust may be gained or lost.

An expectation is that in normal times in highly institutionalized polities, accountability processes are likely to be dominated by apolitical-technical processes aimed at ordermaintenance. When orders are weakly developed, contested or in transformation public attention and citizens' involvement are likely to increase. Accountability processes are politicized and become order-transforming. The following sections explore in more detail how the significance of accountability processes are likely to be affected by the political association and historical experiences of a society, its political organization and institutional arrangements, and political agency and actors' motivations and capabilities.

\section{Political association:}

\section{Unity, diversity and experience}

Individuals associate and dissociate in a variety of ways and demands for accountability are likely to be affected by what unites and divides a population. Examples are the degree of cultural integration in terms of shared values, norms, sentiments, trust and understanding; what individuals think they owe each other and what freedoms, rights and duties they associate with citizenship; the degree of solidarity and the forms and intensity of conflict. Individuals may be selfish and associated by calculation of advantage embedded in contracts. Or they may be tied together by a shared civic identity and an ethos embedded in a pact 
prescribing what is reasonable, fair, and just. To belong to a community means to conduct one's life in ways that are accepted by the community. Behavior is governed by prescriptions and routines based on a logic of appropriateness derived from an identity or role (March and Olsen 1989,1995).

Accountability is a virtue as well as a mechanism (Bovens 2010) and democratic ideals assume that freely associating individuals accept each other as autonomous and equal citizens. The people is supposed to decide collectively what kind of society is worth living in and to give mutually acceptable reasons for how they shall be associated and live together. However, the democratic form of association is at best an achievement and cannot be taken for granted. The belief that democratic citizenship dominates all other identities has to be held up against the possibility of relations characterized by deep-seated distrust and hate and an existential battle between groups that see each other as threatening their form of life. A friend/enemy-relation may be dominant especially in exceptional situations of crisis and emergency (Schmitt 1927).

Democracy as a legitimation principle, furthermore, does not prescribe the terms of association precisely. It is unclear who is to be included in "the people" - whether demos should be constituted on the basis of territoriality, nationality, history, or being affected (Goodin 2007) - and also how different legitimate values are to be balanced (Dahl 1989, Rothstein 2011). The term gives few clear and stable answers when it comes to what accountability is assumed to accomplish and how citizens can effectively call rulers to account.

The term democracy itself gives vague guidance because the term refers to developmental processes of reflection, reason-giving and contestation, rather than static normative and organizational principles. Accountability processes involve more than implementing and enforcing the preferences of predetermined principals. They provide an occasion for contestations of how normative and organizational principles are to be legitimately interpreted and applied. Democracy is an arrangement for developing and transmitting identities and beliefs (Dahl 1989) and encompasses demands for explanation and justification regarding what democratic association is for and what it means to act democratically. There is search for purpose, direction and meaning, and attempts to make 
the world intelligible in normative and causal terms. Intelligence and virtue are products of political action (March and Olsen 1995, Olsen 2014, March 2015).

An implication of the imprecise nature of democracy is that accountability theory needs to take into account that citizens may disagree over forms of political association and that they may change their minds, rather than stick to specific normative and organizational principles. There are likely to be different and shifting visions of how autonomous politics should be in relation to society and disagreement about whether popular participation and representation should have priority in relation to other values and interests. Competing visions of political association are likely to generate different accountability claims, suggesting that it may not be fruitful to assume a static type of association and cleavage structure, predetermined and exogenous to democratic politics. Rather, accountability can be related to dynamic conceptions of association. For example, both internal differentiation and large-scale migration across cultures create heterogeneity and dynamics that complicate the balancing acts involved in governing a territory and population - that is, reconciling unity and diversity, coping with unresolved conflict, making binding decisions and remaining a political community, and reconciling order and flexibility, individual freedom and collective action capabilities.

It may be useful to assume that history matters and that forms of association and accountability demands are influenced by experience with the trustworthiness of representatives, officials and fellow citizens gathered through generations. People can come to believe that decision-makers have to be continuously monitored, kept under scrutiny and held to account in order to prevent misuse of power, or that decision-makers are trustworthy and behave reasonably and justly most of the time (the Scandinavian countries being an example). The more mistrust a people has in its decision makers, the more likely that agents are tightly monitored and called to account.

Different forms of association based on different mixes of unity, diversity and experiences affect the potential for accountability claims. To what extent claims materialize depends on the capabilities of political institutions to deal with diversity and disputes in legitimate ways. Any theory of accountability therefore will benefit from an exploration of how accountability claims are affected by the institutions that frame the roles of citizen, representative and 
non-elected official and organize actors, issues, cleavages, arguments and resources in or out of politics. Participatory, representative and guardian democracies create different access for and require different motivation and capabilities of citizens, thus generating different accountability relations.

\section{Political organization: The ordering ideas, routines and resources of institutions}

Democratic theory usually portrays the individual citizen as the key political unit. Modern political life, however, unfolds within and between large-scale, resourceful organizations and institutions. A behavioral-institutional approach, therefore, gives priority to the organizational basis of accountability - the institutions that tie citizens together or keep them apart and the implications of vesting intelligence, norms, interests, authority and resources in institutional practices. The approach explores what institutions matter and how their characteristics and legitimacy affect accountability processes: namely, how institutions empower and constrain actors, influence what discretion they have and how it is used, and how they authorize some to act on behalf of a community and regulate access to decisions, accommodate or suppress issues, affect the likelihood of violent conflict, and help or hinder citizens to hold rulers to account.

The approach attends to how reliable and competent behavior can be achieved through coercion, rules, incentives, deliberation, bargaining, recruitment, education, socialization and habituation (Olsen 2013,2014,2015). Acceptable behavior can be secured through the external control of opportunity and incentive structures, which make the expected utility of complying greater than non-compliance. Self-control can be achieved through character formation, which ensures that codes of appropriate conduct are understood and respected even when behavior is not monitored (Olsen 2013:460-461,2014:110). The more routines of external and internal controls are seen as legitimate and trusted, the less likely it is that there will be detailed monitoring and intense accountability-claims. The more suspicion there is of ineffective mechanisms, and the more conflict, the more monitoring and accountability demands there will be.

Political organization theory has for some time considered the territorial state to be the prevailing form of organization. The state has been conceived of as a sovereign unitary actor with constituent power, expressing the public will. Norms prescribe a clear allocation of 
authority, power, responsibility and accountability. Focus is often on formal-legal rules. Language is shaped by industrial society. Governmental institutions are interpreted as instruments, apparatus and machinery and a result of organizational engineering and structural choice.

In practice, contemporary democracies are compound, complex and dynamic orders that balance competing normative and organizational principles. State sovereignty is challenged by Europeanization, internationalization, secession, devolution, de-hierarchization and visions of a networked polity/society, and competitive markets. Powers and responsibilities are dispersed between territorial levels of government, institutions of government, and private groups with their own power base. There are competing visions of the role of democratic politics in society and of what are legitimate issues for political contestation and binding, collective decisions. Citizens participate in a variety of ways and authorize several institutions to act on their behalf. There is shifting trust in majority rule, hierarchical command, legal rules, corporatist bargaining, markets and price-systems, expertise, and civil society. Institutions are infused with different ordering ideas about what is to be achieved, how and why. They have routines, resources and some autonomy and they distribute benefits and burdens differently. Institutions are markers of a polity's identity, vision and history and they do not adapt easily to deliberate reforms or shifting circumstances (March and Olsen 1989,1995).

Under such conditions it is probably not fruitful to assume a sovereign principal with normative and coercive authority, command, and control. There are multiple channels of accountability; a variety of mechanisms for rendering, assessing and sanctioning accounts, competing and contested accountability claims, and appeals to different audiences and normative standards (Bovens, Curtin and t'Hart 2008). The importance of elections and hierarchical authorization and accountability depends on the shifting power of votes and elected assemblies. Appointed and self-appointed guardians of order, reason, truth, justice, freedom, and equity have to be held accountable to (some version of) the foundational principles of a democratic-political order. So have organized interests, financial actors, private enterprises, lobbyists, religious leaders, and mass media (Moncrieffe 1998). Accountability theory has to consider non-electoral and non-hierarchical mechanisms of accountability and how different institutions require different motivations and capabilities of 
citizens (Elkin and Soltan 1999). For example, compound polities have different mixes of three (stylized) forms of access structures (Cohen, March and Olsen 1972, Olsen 2015) suggesting different roles for citizens in accountability processes.

Participatory democracy and open structures allow all citizens and issues access to all decision opportunities. A democracy is a community of explanation and justification and informed consent is the basis of governmental authority (March and Olsen 1995:146,150). Citizens have the right to call rulers and each other to account in terms of democratic standards. They have influence through referenda, direct administrative contact, courts, opinion polls, citizens' juries and rights of inquiry, protest demonstrations, civil disobedience and media activity. Still, confidence in rank-and-file citizens has varied over time and modern democracy requires citizens to let representatives act on their behalf. A challenge is to organize governmental institutions in ways that make elected representatives and nonelected officials responsive without the continuous participation of citizens while simultaneously holding them accountable to the public for their (in)actions.

Representative democracy and hierarchical structure is the most legitimate form of order in contemporary democracies. Popular votes and legislative decisions are decisive. There is a chain of authorization and accountability with free public debate, competitive elections, majority law-making and parliamentary and administrative scrutiny as key accountability mechanisms. The elected is agent and the electorate is principal, public administration is agent and legislative, executive and judicial institutions and citizens are principals.

Guardian democracy and specialized structure implies institutional differentiation with institutions at arm's length of citizens and elected representatives. There is more to democracy than majority decisions. Institutions, legitimized by their expertise and integrity are supposed to protect reason, rule of law, inalienable rights and freedoms and to constrain democratic politics. There is institutional autonomy and separation of powers or institutional power-sharing with checks and balances where institutions with different causal and normative beliefs and resources monitor and control each other.

The complications of theorizing democratic accountability in compound polities when the roles of open, hierarchical and specialized structures are contested can be illustrated by the European Union. The EU is a meeting place for competing narratives of political order. There 
is no unitary and stable "people" with a shared identity or notion of accountability. Accountability claims are based upon different conceptions of the nature, purpose and desired future of the Union. They vary among those who see the Union as an intergovernmental, supranational, or regulatory entity (Bovens, Schillemans and 't Hart 2008, Bovens, Curtin and t'Hart 2010). There are appeals to cohesion and solidarity, yet disagreement about facts and causality. The Treaties involve long lists of normative criteria justifying the Union, but they say little about the relative importance of each (Rose 2013:32). There is disagreement about the proper balance between market, judicial and expert power and political-democratic institutions. In brief, Europe faces a struggle over enduring issues related to the terms of political order: the balance between levels of government and between institutional spheres; the relation between the sovereign people and the sovereign individual and between collective and individual responsibilities; the appropriate realms of majority decisions and inalienable rights and freedoms; the importance of citizens' involvement compared to peace and security, economic competitiveness and prosperity, religion, and equal life chances.

The EU claims to draw its legitimacy from its citizens and their trust in the Union depends on perceived benefits of membership, lack of corruption and trust in institutions (Arnold, Sapir and Zapryanova 2012). Considerable resources have been used to prevent and detect fraud. There is well-developed horizontal accountability through institutional checks and balances. Still, critics hold that there is a democratic deficit. EU institutions, they claim, are unrepresentative, non-transparent and not accountable to citizens.

Financial crises have fueled new demands for accountability and one strand of criticism is that priority is given to the Single Market. Economic freedoms are largely insulated from political-democratic processes and political accountability is marginalized. The confidence of financial actors is more important than citizens' trust. There are important reforms without treaty changes and the Community method has been sidelined during the financial crisis. The role of the Troika and selected executive leaders in austerity policies is criticized. Lobbyists are too influential. The Investor-state dispute settlement (ISDS) mechanism of the Transatlantic Trade and Investment Partnership (TTIP) is problematic. Institutional asymmetries redistribute power, dismantle social protection, increase poverty and social inequality, and reduce the EU's and the member states' capacity to deal with global 
capitalism. Within the current institutionalized veto system, feasible democratic reform will not solve these problems. Persistent minorities make majoritarian government problematic. There is a need to de-constitutionalize some economic rights and increase the room for political maneuver, but little enthusiasm for reforms requiring treaty revisions (Scharpf 2015).

The EU has elements of a guardian democracy (Dahl 1989:320). Legitimacy-claims have been based on problem-solving efficiency more than popular participation and democratic process. The European Commission (EC), the Court of Justice of the European Union (CJEU) and the European Central Bank (ECB) are not accountable to citizens. The EC presents itself as an independent and objective guardian of the treaties. The ECJ and the ECB legitimate themselves as expert institutions. Critics, however, hold that guardians extend their mandates, empower themselves, and eschew democratic accountability and control. Many citizens are ambivalent or have lost faith in the European project. There are protest parties and skepticism towards the vision of "an ever closer union". Enlargement projects are replaced by possible departures from the Union. An EU collapse is a thinkable scenario. There is a perceived need to (re)gain the trust of citizens and bridge the gap between those who govern and the governed.

History has mattered. The Union's governance structure was not designed for democratic accountability, and parliamentary accountability is still "remarkably weak" (Weiler 2012:251). There is lack of genuinely European parties, a limited space of public communication and the connections between the results of elections and political developments are loose. Referendum is an instrument to sanction rulers and enforce accountability, but citizens cannot vote government out of office (Rose 2013). Consensus style policy-making makes it difficult to attribute accountability, thereby expanding the space for accountability politics and blame games as well as providing opportunities for actors to cultivate their reputation and legitimacy (Busuioc and Lodge 2015).

A possible lesson is that intense accountability-demands are likely in polities in transition where competing conceptions of accountability-regimes and political orders collide. The terms of order are influenced by historic and existing power relations. The ability to call others to account and remain unaccountable is an indicator of power (Day and Klein 1987:9) 
and accountability-demands are likely when power relations and the causal and normative beliefs and interests they are based upon are challenged or changed. Political conflict can be a source of incremental change or of the breakdown of an old order and the emergence of a new one based on different principles. Conflict can be an engine of learning, emancipation and progress or of suffering and destruction, and tensions ca escalate due to a tendency to find mitigating circumstances for friends and blame adversaries.

Arguably, mechanisms of institutional specialization, separation and autonomy help the EU to cope with inconsistent accountability-claims that create conflicts and stalemates at constitutive moments (Olsen 2007 Ch. 9,2010). Still, the more complex, conflict-prone and dynamic a political order is, and the more interdependence, power-sharing and compromises it accommodates, the more room that order has for accountability politics and competing interpretations of what has happened, why it happened, whether what happened is good, and whether things could have been done differently. Under such conditions, it can be an insurmountable task to objectively disentangle the contribution of specific actors and institutions, attribute responsibility, blame and praise, and hold actors to account democratically (Easton 1975, March and Olsen 1995:157-158). Sometimes there are fact-free claims of accountability deficits (Bovens, Curtin and t' Hart 2010) and "emotional storytelling" (Galeston 2010).

Political institutions, however, provide a framework that affects but does not determine how things are understood, justified and acted upon. Institutions exist because a sufficiently high number of citizens believe they exist (Searle 1995) and democratic institutions need the support or acquiescence of the governed. They require continuously renewed collective confirmation and validation of their constitutive rules, meanings and resources, and it is difficult for public officials to not give an account without losing legitimacy. Accountability and orderly change are supported by legitimation of critical reflection, debate and organized opposition. But, what is the role of political agency and how motivated and capable are citizens when it comes to participate in accountability processes? When are accountability processes likely to take place within specialized-apolitical or hierarchical-political structures? When are open structures more important, attracting many participants and issues? The next section considers the role of shifting public attention, citizens' zone of acceptance, and resources and action capacity. 
Political agency: Attention, acceptance and capabilities

Accountable government implies purposeful agency - discretion, will, reasoning and deliberate choice - rather than determinism (a divinely ordained or natural order) or pure chance, and it is consistent with democratic faith to argue that "choice in politics is both possible and necessary". Things do not need to be the way they are. In a democracy, "the last word goes to the politicians and in the end, via the process of accountability, to the voters". Political leaders have significant control and can be assigned responsibility. Their decisions can be understood and assessed by citizens (Lewin 2007:180,182).

Nevertheless, conceptions of well-informed citizens calling power-holders to account on issues that are important for them (Hutchings 2005) have to be held together with an old observation. Being a citizen does not appear to be an important role, nor political participation an intrinsic good. Participation in public affairs is regarded with indifference by vast numbers of citizens. Popular interest in political matters remains sporadic. The average citizen seems to find the exercise of political rights burdensome, boring, and often lacking in significance. Politics possesses little prestige. The individual increasingly seeks political satisfaction outside the traditional area of politics (Wolin 1960:353).

In brief, the idea of well-informed, rational and active citizens is a democratic norm that is not always realized and accountability theory cannot assume that access opportunities are used continuously. The entire population is rarely activated. People may lack motivation and/or action capabilities. Thus, if it is assumed that accountability processes normally are dominated by professionals and the standard operating procedures of specialized and hierarchical institutions, and that most citizens are unlikely to participate most of the time, when are open structures likely to attract large numbers of citizens and issues?

Calls for accountability may follow from shifting public attention. During normal times most political-administrative decisions are made without public attention. Accountability processes are driven by routine scrutiny involving accountants and auditors, political and organizational leaders, and ready-to-use narratives that provide explanations and justifications and assign praise and blame. The public is activated by extraordinary events, disasters, performance crises, scandals or conflicts. Unexpected major threats may evoke 
appeals to unity, activating citizens within institutionalized channels of participation or to issues that divide a population, mobilizing citizens in disruptive forms.

The public is also likely to be activated by more enduring political contestation over the terms of political order, and changes in the international discourse during the last decades have generated more and different accountability demands. Claims have been raised because institutionalized expectations have not been met and also because causal beliefs, success-criteria and power-relations have changed. Demands for direct democracy and democratization of all major social institutions during the 1970s have since the 1980s been replaced by economic neo-liberalism, individualism, and ideals of commercial life, together with neo-constitutionalism and ideals of protecting individuals against political authorities through legal guarantees. Anti- and apolitical impulses have been nurtured, discrediting politics and calling renewed attention to threats of state coercion, majority tyranny and "bureaucracy". Preventing government from abusing political power and doing harm, and protecting the freedoms of individuals by reducing the public agenda, demanding rulebound exercise of political authority, and giving priority to social, economic and cultural institutions, have been prioritized over enabling government to solve common problems.

The New Public Management ideology has been a driving force for public sector reforms and new accountability demands (Lægreid 2014) and the "reinventing government" movement has used a less anti-political and more apolitical language, advising better rather than less government and public services (Saint-Martin 2001). The public sector has been assumed to work better and cost less by using standardized measures, quantifiable indicators, administrative control systems, and by empowering customers and clients. Belief in network governance and making public officials accountable via market-like mechanisms has replaced belief in hierarchical government. Priority has been given to economy and efficiency - to how rather than what and why-issues.

New accountability-claims followed from elections and shifts in governmental power. Politicians contributed to anti-political attitudes and accountability claims by creating unrealistic expectations by promising more than they could keep in order to win elections and by describing opponents in negative terms, tendencies strengthened by a "culture of cynicism" in the mass media (Hay and Stoker 2009). The realm of democratic politics was 
challenged by end-of-history narratives portraying global markets and the liberalconstitutional state as the institutional foundations of society. Traditional politicaldemocratic rights were dismantled through transnational processes - free trade agreements and international dispute settlement bodies protecting investors and private economic rights, with a norm-making and polity-building character across policy-areas (Isiksel 2013:194). The room for political maneuvering was also affected by a rights revolution and the transfer of "an unprecedented amount of power from representative institutions to judiciaries"; an empowerment of a juristocracy (Hirschl 2004:71).

The reforms illustrate that accountability processes are part of a struggle over people's minds, their expectations and their aspiration levels, and accountability-demands are likely to depend upon citizens' zone of acceptance (Simon 1957:12). Citizens' zones of acceptance defines legitimate purposes, powers, methods and outcomes and the ruled are unlikely to call decision makers to account if rulers routinely anticipate what citizens see as legitimate, exercise self-restraint, stay within the zone of acceptance, and report about their practices and results to the satisfaction of citizens. Amnå and Ekman (2014), for instance, observe the importance of standby citizens. These are citizens who are informed, competent, resourceful and interested in politics, yet remain inactive. They trust political institutions and actors. Accountability is assumed to be taken care of by those whose duty it is to do so and specialized actors and routines are seen to work reasonably well. Standby citizens are willing and able to participate, but not continuously, and not as long as they think their concerns are attended to even when they do not participate in active supervision, monitoring and scrutiny of rulers.

Increased accountability-demands are likely to follow from changes in knowledge, norms and power relations that generate discontent and disillusion with an order's cognitive, normative, and power-bases. These are situations where the basic assumptions on which a political order is instituted are discredited as being illegitimate, inefficient, immoral, or exploitive. Existing explanations and justifications are no longer seen to make sense. Trust is eroded and prescriptions not obeyed. Citizens can gradually lose faith in institutions and actors, or specific events can lead to radical change. Increasing demands for accountability are especially likely when expectations and aspirations are generally disappointed, when 
there are unsatisfactory explanations and justifications, or when conflicts are seen as threatening.

Whereas struggle over the terms of political order is likely to attract attention, challenge peoples' zones of acceptance and activate accountability demands, calling rulers to account and sanctioning them requires adequate resources and alternative sources of information. For democracies, it is difficult to reconcile the ideal of political equality with increasing socioeconomic inequality. Power based on number of votes competes with power based upon economic, organizational, informational and military resources and accountability-claims are likely to be affected by citizens' action capabilities. While citizens may not call rulers to account because they are satisfied with their performance, they may also be inactive because they believe they have no chance to make a difference; for example, if they are disillusioned and feel apathetic, fatalistic, or powerlessness; or if they think that politics is none of their business, politicians are corrupt and they do not listen to people like them (Amnå and Ekman 2014).

The European Union illustrates that disengagement is an alternative to increased accountability-demands and that efforts to strengthen citizens' involvement are not always successful. As part of the Union's attempts to change its image, 2013 was declared the "European Year of Citizens", dedicated to citizens' rights in shaping the future of Europe. The Citizens' Initiative, which gives European citizens the right to petition the Commission, however, requires organizational muscles. To be taken up by the Commission, an initiative has to be backed by at least one million citizens from at least seven member states, with a minimum number from each state. The Commission promises to examine initiatives, but is not obliged to propose legislation. The results of this and several other participatory mechanisms have been modest (Boussaguet 2016).

The same is true for the "New Narrative for Europe" initiative. This initiative invites citizens and in particular artists, intellectuals and scientists to debate the future of Europe. Europe is seen to need a new narrative, a collective normative commitment and positive emotions that can reconnect citizens with European ideals. Europe is presented as a moral and political responsibility which has to be carried out not only by institutions and politicians, but by all Europeans. Nevertheless, it has been asked whether a grand narrative educating the 
people is needed, or whether the challenge is to listen to what people have to say and live up to European ideals (Battista, Setari and Rossignol 2014:126,129).

The European case also raises questions about to what degree rulers actually control the terms of political order and can legitimately be called to account when these terms shift. A new multi-level and multi-centered order is evolving through complex interactions between supra-national, intergovernmental, and transnational processes rather than following a single master plan (Olsen 2007,2010). A democratic vision is that democracies are able to change incrementally and adapt to a variety of shifting opportunities and challenges. Yet, the importance of intention and consistent structural choice in the development of political orders varies. It is contested to what degree political institutions are, or even can be, deliberately structured and re-structured, or whether they are evolving incrementally over time as an unplanned artifact of historical processes (Mill 1861, March and Olsen 1983). Institutions formed under specific historical circumstances are used to solve problems in quite different historical-institutional contexts. Complex and dynamic orders composed of multiple interacting components are unpredictable and uncontrollable. Feed-back is more or less fast, reliable, and easy to interpret. There are complicated loops and imperfect learning (March 2010). Institutional change characterized by co-evolution, rather than a single dominant process and driving force, makes it difficult to objectively attribute responsibility and facilitates political contestation over who-is-accountable-for-what, as well as what constitutes appropriate accountability regimes and a legitimate order.

It may be useful for accountability theory to examine under what conditions institutional choice is a tool for pre-established principals, rather than to take for granted that politicaladministrative institutions and traditions are easily malleable. It may also be useful to examine the belief that experiential learning secures improvement, or in other words, that progress is guaranteed through a self-organizing and self-correcting polity driven by free debate in civil society, electoral competition among political parties, pluralistic bargaining among interest groups, competitive markets, or scientific and technological progress.

Theories of accountability have to address both limitations in rulers' control and citizens' obligations. First, given the particular roles, relations and powers that structure democratic politics, a political virtue is to act well. However, action is also demanded, or believed to be 
demanded also when governments are impotent with respect to the issues they face (Philp 2010). Governing implies making efforts to improve things under conditions of conflicting values, unobtainable objectives, causal uncertainty, inadequate resources and uncertain control. Second, the observation, that accountability problems can be located in principals rather than agents (Schillemans and Busuioc 2014), has relevance for citizens as the ultimate source of democratic power. Making unattainable accountability-claims may cause trust in the political order to decline - a possibility more likely if it is correct that the ancient idea that citizens, as responsible members of a political community, are accountable to each other for their performance, is alien to modern democracies (Borowiak 2011:93,97).

To conclude, increasing demands for explanations, justifications and sanctions can be interpreted as a positive democratic phenomenon. Today's citizens are more capable and demanding, with a growing confidence in their own political opinion. There is less deference to hierarchies and less fear of authorities (Hay and Stoker 2009). Authority has become reflexive rather than based upon subordinates' willingness to follow commands of superiors while holding their own assessment of alternatives in abeyance (Simon 1957:126). Increasing accountability-demands can, however, also be interpreted as overburdening democracies (Crozier, Huntington and Watanuki 1975:9) when governments are called to account for things they do not control.

\section{Theorizing democratic accountability: Back to the roots}

Theorizing democratic accountability and the role of citizens calls attention to issues ranging from whether a single rule is broken or a budget misused to contestations over political order. It involves approaches ranging from book-keeping and the discipline of accounting to institutional approaches viewing the development of accounts as a core task of governance, on par with developing political identities and rules of appropriate behavior, organizational capacities and political adaptiveness (March and Olsen 1995:44-45). Some prefer a restricted use of accountability linked to specific institutional spheres and actors, in particular elections, voters and formal-legal authorities. This paper takes seriously the idea that democratic citizens have the right to call their rulers and each other to account and presents a dynamic conception of what accountability means and implies under different institutional circumstances. 
The obsession with accountability has been interpreted as part of a struggle over the terms of political order in a period when the legitimate position of different territorial levels of government and the role of democratic politics in society are contested. In such periods, more is at stake in accountability processes than an apolitical, technical clarification of facts and causality and disciplining incompetent or unruly agents. To theorize accountability processes implies exploring multiple accountabilities in shifting contexts as well as some timeless aspects of political organization. That is, to combine an interest in a shifting studyobject with a return to the roots of the discipline: the normative-ethical, causal, and power basis of different orders and the role of citizens in constituting and changing the terms of political order and accountability regimes. Rather than assuming highly institutionalized and static democracies, accountability processes may be seen as part of an historical struggle between order and reform (Mill 1956:57-58) and a possible transition to a new and yet unrealized or unrecognized political order (Bendix:1968:9).

Historically, Europe has experienced many forms of political organization: city-state, feudal state, empire, nation-state, and the territory of Christendom. As earlier political orders have evolved and become outdated, they have come to embody ignorance, superstition, prejudices, oppression and obstacles to progress. There have been institutional breakdowns due to war, civil war, revolution, counterrevolution and coup d'état. The nation state has been hailed as an agent of civilization and condemned as a source of human disaster. Since World War II Europe has tried to adapt to the loss of world hegemony, a global redistribution of power and new interdependencies, the fall of the Berlin wall in 1989, the economic crisis since 2008, and large-scale migration. A new type of polity is emerging, activating enduring issues about the terms of order. Who shall be part of the political community? How much unity and diversity is viable? What do citizens expect from government and from each other? How is government to be organized? What are acceptable agendas, purposes and normative standards? What are legitimate instruments for interfering in the lives of citizens? How can rulers be held accountable?

Mainstream political science has, however, shown only modest interest in developing behavioral theories of political organization after World War II, in spite of the fact that students of political life historically have viewed establishing and maintaining political order as a core governmental task (Wolin 1960). They have seen well-organized institutions as a 
precondition for civilized co-existence and have explored how political organization affects the well-being of citizens. Many factors have contributed to these developments. There has been considerable formal-legal institutional stability in western democracies during the period and strong democratic-legal norms regarding how political institutions shall be understood. Academic specialization has focused attention on single institutions more than the political order at large. "Idealist" political theory assuming normative standards and rights exogenous to politics has generated a "displacement of politics in political theory" (Galston 2010:386-387). Political science has not regarded organization theory as particularly relevant (Olsen 1991), a tendency strengthened as organization theory has migrated to business schools.

This paper invites the discipline to rethink what democratic accountability is all about, what it is assumed to accomplish and the possible relevance of political association, organization and agency. It is likely to be fruitful to contextualize assumptions of normative democratic thought and principal-agent approaches which treat key aspects of accountability processes as exogenous to democratic politics and assume that accountability is secured by an arrangement of institutions organized by different logics and linked in a neat sequence of separate action: The world is divided into sovereign states, within which opinion- and preference formation are freely formed in civil society and a public sphere. Rulers are selected, authorized, made accountable and removed through competitive elections. Elected representatives make laws binding for all. Accountability implies consistency with the law and representatives scrutinize how laws are executed. The rule of law assumes a clear distinction between making the law and enforcing it, and between the realm of politics, public administration, and the judiciary. Effective accountability mechanisms safeguard the ability to learn from experience and guarantee orderly transfer of powers, survival and progress.

These assumptions are not reliably met in contemporary democracies. State borders are increasingly porous and influence goes in many directions. Action is interconnected with extensive feedback-loops and outcomes are difficult to predict and control. The formation of opinion and preferences is affected by resourceful, organized actors, a professional communication industry, new communication technologies and social media. Citizens participate in a variety of channels, beyond elections. Colliding democratic visions generate 
different accountability-claims. The role of democratic politics is uncertain and the Westminster-ideal of a sovereign parliament, authorized to do anything except binding the next parliament, has limited support. The politics-administration dichotomy is problematic, as are assumptions about administrative hierarchies. Courts make, as well as interpret laws. Learning is imperfect and experience does not guarantee improvement and equilibrium solutions.

This paper does not aspire to provide final answers about how accountability processes work in modern democracies. It invites debate and empirical studies of the organizational basis of democratic accountability and how the significance of accountability processes, and citizens' perceived need and ability to call rulers to account, are likely to be affected by shifting terms of political order. A dynamic conception of democratic accountability suggests that: (a) political association involving different mixes of unity/diversity, trust/mistrust and historical experiences generate different potentials for accountability claims; (b) political organization and institutionalized behavioral routines, ordering ideas and resources, make a polity more or less able to cope with divisions and generate acceptable solutions, and affect the felt needs and the options for the ruled to hold rulers accountable; and (c) political agency and different and shifting public attention, zones of acceptance, and action capabilities influence which available options are actually used.

Understanding how political orders affect accountability processes is a first step in theorizing the relationship between democratic accountability and political organization. The next step is to explore in more detail how order-maintaining and order-transforming accountability processes affect political orders, their democratic quality, and the possibility of civilized coexistence.

\section{Literature}

Amnå, E. and J. Ekman 2014, Standby citizens: diverse faces of political passivity. European Political Science Review 6 (2):261-281.

Arnold, C., E.V. Sapir and G. Zapryanova 2012, Trust in the institutions of the European Union: A cross-country examination. In L. Beaudonnet and D. Di Mauro (eds.): Beyond Euroskepticism: Understanding attitudes towards the EU. European Integration online Papers (EloP), Special Mini-Issue 2, Vol. 16, Article 8, http://eiop.or.at/eiop/texte/2012-008a.htm 
Battista, E., N. Setari and E. Rossignol 2014, The Mind and Body of Europe: A New Narrative. Luxemburg: Publication Office.

Bendix, R. (ed.) 1968, State and Society. Boston: Little, Brown.

Borowiak, C.T. 2011, Accountability \& Democracy. The Pitfalls and Promises of Popular Control. Oxford: Oxford University Press.

Boussaguet, L. 2016, Participatory mechanisms as symbolic policy instruments? Comparative European Politics 14 (1): 107-124.

Bovens, M. 2010, Two concepts of accountability: Accountability as a virtue and a mechanism. West European Politics 33 (5):946-967.

Bovens, M., D. Curtin, and Paul 't Hart 2010, The Real World of EU Accountability. What Deficit? Oxford: Oxford University Press.

Bovens, M., R.E. Goodin and T. Schillemans (eds.) 2014, The Oxford Handbook of Public Accountability. Oxford: Oxford University Press.

Bovens, M., T. Schillemans and P. 't Hart 2008, Does public accountability work? Public Administration 86:225-242.

Busuioc, E.M. and M. Lodge 2015, The reputational basis of public accountability. Governance, DOI: 10.111/gov.12161

Cohen, M.D., J.G. March and J.P. Olsen 1972, A garbage can model of organizational choice. Administrative Science Quarterly 17: 1-25.

Crozier, M.J., S.P. Huntington and J. Watanuki 1975, The Crisis of Democracy. New York: New York University Press.

Dahl, R.A. 1989, Democracy and Its Critics. New Haven: Yale University Press.

Day, P. and R. Klein 1987, Accountabilities: Five Public Services. London: Tavistock.

Dubnick, M.J. 2011, Move over Daniel: We need some "accountability space". Administration \& Society 43:704-716.

Easton, D. 1975, A reassessment of the concept of political support. British Journal of Political Science 5 (4):435-457.

Eisenstadt, S.N. 1995, The order-maintaining and order-transforming dimensions of culture. Reprinted in S.N. Eisenstadt: Power, Trust and Meaning: 306-327. Chicago: University of Chicago Press.

Elkin, S.L. and K.E. Soltan (eds.) 1999, Citizens Competence and Democratic Institutions. University Park: The Pennsylvania State University Press. 
Gailmard, S. 2014, Accountability and principal-agent theory. In M. Bovens, R.E. Goodin and T. Schillemans (eds.), The Oxford Handbook of Public Accountability:90-105. Oxford: Oxford University Press.

Galston, W.A. 2010, Realism in political theory. European Journal of Political Theory 9 (4):385-411.

Goodin, R.E. 2007, Enfranchising all affected interests, and its alternatives. Philosophy \& Public Affairs 35 (1):40-68.

Hay, C. and G. Stoker 2009, Revitalising politics: have we lost the plot? Representation 45 (3):225-236.

Hirschl, R. 2004, The political origins of the New Constitutionalism. Indiana Journal of Global Legal Studies 11 (1):71-108.

Hutchings, V.L. 2005, Public Opinion and Democratic Accountability: How Citizens Learn About Politics. Princeton: Princeton University Press.

Isiksel, T. 2013, Citizens of a new agora: Postnational citizenship and international economic institutions. In W. Maas (ed.): Multilevel Citizenship:184-202, 261-271. Philadelphia: University of Pennsylvania Press.

Lægreid, P. 2014, Accountability and the New Public Management. In M. Bovens, R.E. Goodin and T. Schillemans (eds.), The Oxford Handbook of Public Accountability:324-338. Oxford: Oxford University Press.

Lewin, L. 2007, Democratic Accountability. Why Choice in Politics is Both Possible and Necessary. Cambridge: Harvard University Press.

March, J.G. 2010, The Ambiguity of Experience. Ithaca NY: Cornell University Press.

March, J.G. 2015, Do the mistakes lie in decision makers or in economics? In S. Rangan (ed.): Performance and Progress:28-37. Oxford: Oxford University Press.

March, J.G. and J.P. Olsen 1983, Organizing political life: What administrative reorganization tells us about government. The American Political Science Review 77 (2):281-296.

March, J.G. and J.P. Olsen 1989, Rediscovering Institutions. The Organizational Basis of Politics. New York: Free Press.

March, J. G. and J. P. Olsen 1995, Democratic Governance. New York: Free Press.

March, J.G. and J.P. Olsen 1998, The institutional dynamics of international political orders. International Organization 52 (4):943-969.

Mill, J.S. 1956 [1859], On Liberty. Indianapolis: Bobbs-Merrill. 
Mill, J.S. 1962 [1861], Considerations on Representative Government. South Bend Ind.:Gateway Editions.

Moncrieffe, J.M. 1998, Reconceptualizing political accountability. International Political Science Review 19 (4):387-406.

Mouffe, C. 2005, Democratic Citizenship and the Political Community. In C. Mouffe: The Return of the Political: 60-73. London: Verso.

Olsen, J.P. 1991, Political Science and organization theory. Parallel agendas but mutual disregard. In R.M. Czada and A. Windhoff-Héritier (eds.): Political Choice: Institutions, Rules and the Limits of Rationality:87-119. Frankfurt am Main: Campus Verlag.

Olsen, J.P. 2007, Europe in Search of Political Order. Oxford: Oxford University Press.

Olsen, J.P. 2010, Governing Through Institution Building. Institutional Theory and Recent European Experiments in Democratic Organization. Oxford: Oxford University Press.

Olsen, J.P. 2013, The institutional basis of democratic accountability. West European Politics 36 (3):447-473.

Olsen, J.P. 2014, Accountability and ambiguity. In M. Bovens, R.E. Goodin and T. Schillemans (eds.), The Oxford Handbook of Public Accountability:106-123. Oxford: Oxford University Press.

Olsen, J.P. 2015, Democratic order, autonomy and accountability. Governance 28 (4):425440.

Philp, M. 2010, What is to be done? Political theory and theoretical realism. European Journal of Political Theory 9 (4):466-484.

Pollitt, C. and P. Hupe 2011, Talking about government. The role of magic concepts. Public Management Review 13 (5): 641-658)

Rose, R. 2013, Representing Europeans A Pragmatic Approach. Oxford: Oxford University Press.

Rothstein, B. 2011, The Quality of Government: Corruption, Social Trust and Inequality in a Comparative Perspective. Chicago: The University of Chicago Press.

Saint-Martin, D. 2001, How the reinventing government movement in public administration was exported from the U.S. to other countries. International Journal of Public Administration $24(6): 573-604$.

Scharpf, F.W. 2015, After the crash: A perspective on multilevel European democracy. European Law Journal 21 (3):384-405. 
Schillemans, T. and M. Busuioc 2014, Predicting public sector accountability: From agency drift to forum drift. Journal of Public Administration Research and Theory 25 (1):191-215.

Schmitt, C. 1976 (1927), The Concept of the Political. New Brunswick, NJ: Rutgers University Press.

Searle, J.R. 1995, The Construction of Social Reality. London: Penguin.

Simon, H.A. 1957 ( $2^{\text {nd }}$ ed.), Administrative Behavior. New York: Free Press.

Weiler, J.H.H. 2012, Europe in crisis - on 'political Messianism', 'legitimacy' and 'the rule of law. Singapore Journal of Legal Studies. December:248-268.

Wolin, S.S. 1960, Politics and Vision. Continuity and Innovation in Western Political Thought. Boston: Little, Brown \& co. 